\title{
Al-Qur'an Speech Therapy for Children with Autism
}

\author{
Evi Chamalah, Meilan Arsanti \\ Sultan Agung Islamic University, Indonesia \\ E-mail: chamalah@unissula.ac.id
}

\begin{abstract}
A study conducted by the Center for Disease Control (CDC) in the United States in 2008 stated that the ratio of autism in children aged 8 years diagnosed with autism was 1:80. From Hong Kong research study in 2008, it was reported that the prevalence of the incidence of autism in Asia was 1.68 per 1000 for children under 15 years old. Semarang Autism Therapy Center is one of the autism therapy centers in Semarang. The foundation has approximately 9 children with autism. Several therapies have also been occupied, such as ABA, speech and occupational therapy, yet the results were less significant. Therefore, researchers want to offer a new therapy Method by the name Alquran Speech Therapy. This therapy is a combination between speech therapy and the Quran. Based on the identification of the problem, then the purpose of this study is to describe the implementation of Alquran Speech Therapy method in healing children with autism in Semarang autism therapy center. Based on the research, the result can be concluded that there is positive effect of giving the children suffering from autism speech therapy with Quran recitation. They can be calm and happy in learning process.
\end{abstract}

Key Words: speech therapy, the quran, autistic children

\begin{abstract}
Abstrak: Sebuah studi yang dilakukan oleh Center for Disease Control(CDC) di Amerika Serikat pada tahun 2008 menyatakan bahwa rasio autisme pada anak usia 8 tahun yang didiagnosis dengan autisme adalah 1:80. Dari penelitian yang dilaksanakan di Hong Kong tahun 2008, dilaporkan bahwa prevalensi kejadian autisme di Asia adalah 1,68 per 1000 untuk anak di bawah 15 tahun. Pusat Terapi Autisme Semarang adalah salah satu pusat terapi autisme yang berlokasi di Semarang. Yayasan ini memiliki sekitar 9 anak autis. Beberapa terapi juga telah diduduki, seperti ABA, terapi bicara dan pekerjaan, namun hasilnya kurang signifikan. Karena itu, peneliti ingin menyarankan metode terapi baru dengan nama Alquran Speech Therapy. Terapi ini merupakan kombinasi antara terapi wicara dan Alquran. Berdasarkan identifikasi masalah tersebut, maka tujuan dari penelitian ini adalah untuk mendeskripsikan penerapan metode Terapi Alquran Speech dalam penyembuhan anak autis di pusat terapi autisme Semarang. Berdasarkan hasil penelitian, dapat disimpulkan bahwa ada pengaruh positif pemberian anak penderita terapi wicara autisme dengan pembacaan Alquran. Mereka dapat tenang dan bahagia dalam proses belajar.
\end{abstract}

Kata kunci: terapi bicara, quran, anak autis

The development of children born with mental retardation or autism is very different from children born to normal. In the world of children, education, and medicine, we often hear the term autism. Autism comes from the Greek autos which means self or to be in his own world (Rahayu, 2014, p. 421). Autism can be said to be an extremely complex developmental disorder in children. The developmental disorder usually begins to appear before the age of three. This condition makes the children unable to communicate or express their desires, resulting in disruption of behavior and relationship with others (Pratiwi et al, 2014).
In general, the characteristics often found in children with autism are having difficulties to cope with other children, laughing or giggling at anyplace, avoiding eye contact or just a little eye contact, showing insensitivity to pain, prefer of being alone, appealing themselves from the association, not forming a personal open relationship, being fixated on certain objects, dependent upon the object already known, having too physically active or completely inactive, and so forth (Hartono and Poppy, 2014).

The Director of Mental Health Care, Ministry of Health, Diah Setia, said that there were about 112,000 
children with autism in Indonesia, in the age range of about 5-19 years. According to her, if it were assumed with autism prevalence of 1.68 per 1000 for children less than 15 years, of which the number of children aged 5-19 years in Indonesia reached 66,000,805 inhabitants based on BPS data in 2010, there would be more than 112,000 autistic children in the age range 5-19 years old. The opinion was stated at the seminar of "Diagnosis accurate, right education dan strongher supported to create good future for autism child in Jakarta (Republika, 2013).

According to Setia (in Republika 2013), data of children with autism in various parts of the world show vary in number. Based on data from UNESCO in 2011, there were about 35 million people with autism around the world. This means an average of 6 from 1000 people in the world suffer from autism. Results of the Research Center for Disease Control (CDC) in the United States in 2008 found that the ratio of autism in children aged 8 years who were diagnosed with autism was 1:80. Based on the results of the Hong Kong Research Study in 2008, it was reported the prevalence of incidence rate of autism in Asia was 1.68 per 1000 for children under 15 years old.

Setia (in Republika 2013) also said that autism is a complex developmental disorder with symptoms on the difference and inability in various fields such as communication skills, motor skills, and social interaction. Furthermore, genetic, drugs and metal consumption factors through food can cause children to become autistic. The question that often arises is whether children with autism can be cured or not. There are many various kinds of therapy performed to treat autistic children. There are 10 kinds of therapies which are often performed, as follows.

First, Applied Behavioral Analysis (ABA). ABA is a type of therapy that has been used and applied in some research, and it is designed specifically for children with autism. The system used is given special training in children with gifts or praise. This type of therapy can be measured its progress. At this time, the therapy is the most widely used in Indonesia.

Second, Speech therapy. Almost all children with autism have difficulties in speech and language. Usually it is the most prominent, many children with autism are nonverbal or having less speech. Sometimes their speech is developing, but they are unable to use this speech to communicate or interact with others. In this case, the speech and language therapy can be very helpful.
Third, Occupational therapy. Almost all children with autism have delays in soft motor development. They have stiff and rough movements, they are difficult to hold a pencil in the right way, hard to hold the spoon and feed it into the mouth, and so forth. In this case, occupational therapy is very important to train the muscles correctly.

Fourth, Physical therapy. Autism is a pervasive developmental disorder. Many individuals with autism have impaired development in gross motor, sometimes flabby muscle tone, so that the course is less strong. As result, their balance is not good. Physiotherapy and sensory integration therapy will help them very much to strengthen muscles and improve balance.

Fifth, Social therapy. The most fundamental deficiency for individuals with autism is in the field of communication and interaction. Many children need help in two-way communication skills. A social therapist helps them by providing facilities for them to socialize with peers and to show the ways.

Sixth, Play therapy. Despite the strange hearing, an autistic child needs help in learning to play. Playing with peers is useful to learn to speak, communicate, and have social interaction. A therapist can help children play in this regard by certain techniques.

Seventh, Behavior therapy. Autistic children often feel frustrated. Their friends often do not understand them; they find it difficult to express their needs. Many of them are hypersensitive to sound, light, and touch. Not surprisingly, they often upset easily. A behavior therapist is trained to look for the background of the negative behavior and find a solution to the environmental changes and routinely recommend the child to improve his behavior.

Eighth, Therapeutic development. Floor time, Son-rise and RDI (Relationship Developmental Intervention) is considered as a therapeutic development. This means that children are taught their interests, powers and development levels, and improved social skills, emotional and intellectual. The developmental therapy is different with behavioral therapy such as ABA therapy; it is much more specific on teaching skills.

Nineth, Visual therapy. Autistic individuals more easily learn by seeing (visual learners/visual thinkers). This therapy, it is then used to develop learning methods of communication through pictures, for example by using the Picture Exchange Communication System. Some video games can also be used to develop communication skills. 
Tenth, Biomedicine therapy. Biomedical therapy is developed by a group of physicians who are members of the DAN (Defeat Autism Now). Many of the pioneers have autistic children. They are very persistent to do some research and found that the child's symptoms are compounded by the presence of metabolic disorders that would have an impact on brain function disorders. Therefore, these children are examined intensively, includes examination of blood, urine, feces, and hair. All things found to be abnormal are cleared away, so that the brain can be sterile from obstructions. As a result, more children are progressing when they get comprehensive therapy, i.e., therapy from outside and inside the body itself (biomedical).

Several therapies have also been made as disclosed in the following study. The first study conducted by Suryawati (2010) with the title "Model of Communication Management for Autistic Children through Music Therapy with LOVAAS Method". The results of the study showed (1) the severity of the degree of abnormality, the more severe the degree of abnormality and the type of behavior disorders is, the more difficult the children to return to normal; (2) the age of the child first handled properly and regularly, the ideal age is 2-3 years, because at this age, the most rapid brain development occurs; (3) the intensity of treatment, LOVAAS method sets for 40 hours /week; and (4) in the case of a child's IQ, the more intelligent the child is, the sooner he captures the material provided. However, it should be noted that in addition to the intelligence quotient, emotional quotient must be trained as well, for many children, especially autism children who have trouble in controlling emotions.

The second study is conducted by Kusmitantia (2012) with the title "Dance Lessons by Using LEAP Method for Improving Goal of Occupational Therapy in Autistic Children at SLB Bina Anggita Yogyakarta". The results of this study showed (a) the ability to dance of students with autism increased from cycle I to cycle II which was marked by an increase in the average score of 13.37 of wiraga aspect, then wirama aspects of 11.67 and through observation of the prior and post implementation action; (b) the increase in the dancing abilities affected the increased target of occupational therapy of students from the first cycle to the second cycle, which could be seen from the increase in the physical aspect score of 8.33 ; intellectual of 15 ; social of 12.50; emotion of 10 , and through the observation of the prior action after the implementation of the action.
The third study is by Marienzi (2012) entitled "Improving the Ability to Know Figures through multisensory method for Autistic Children". The results of this study showed that after given intervention by using multisensory methods, children then could recognize the concept of the numbers properly, with a comparative percentage of $46.25 \%$ in A and $95 \%$ in B Condition.

The fourth study is conducted by Sukmawati (2014) entitled "The Effectiveness of Picture Exchange Communication System (PECs) Method to Improve Language Skills in Autistic Children". The results showed that there was an improvement in behavior of pointing, mentioning and saying from baseline to intervention session. The changes in level that occur between conditions showed an improvement followed by a trend which is increasing rapidly. Behavior of subject $1(\mathrm{JN}), 2(\mathrm{AM})$, and $3(\mathrm{RF})$ on the ability of pointing and saying, improved from the low category into the high category. The ability to say has improved from the low category into the middle category. This indicates that the implementation of the PECS methods effectively improves behavior of pointing, mentioning, and saying as part of the language skills of children with autism at kindergarten for special needs children in Pontianak.

The fifth study is entitled "the Effect of ABA Therapy on Social Interaction in SLB Pranada Bandung" written by Adjeng and Hatta (2015). From the results, it can be seen that as many as 11 people or $73 \%$ of the subjects may have social interaction. This means that ABA (Applied Behavior Analysis) therapy plays a role in the formation of social interaction in children with autism at SLB Pranada Bandung. The highest effect of social interaction dimension is in the dimension of imitation by $87 \%$ and social sympathy by $93 \%$. The method used in that study was quasi experiment aimed to figure out the effect of ABA therapy to children with autism in social interaction.

The results of the therapy conducted by researchers above were less significant in students with autism in the Foundation for Autism Therapy in Semarang. This Foundation is one of the longest autism therapies in Semarang precisely at Afa Perum Permai Semarang. This foundation therapy center has about 9 children with autism. From the various therapies that have been done, the researchers would like to offer a new therapy method by the name of the Alquran Speech Therapy. This therapy combined between speech therapy and Alquran. 
We need to keep in mind that the best means of treatment or handling and the most useful is the Koran Karim, the word of the Lord of the Worlds, which connects His servants with the Creator. It has been affirmed in the religious texts that Alquran is the most useful and effective healing medium for treating various ailments both physical and spiritual. Indeed, the conditions must be faithful and unhurried. In detail, it has been proven in the reality of human life since the time of the Prophet until today, where many human beings can get benefit by treatment with Alquran. In addition, treatment with Alquran has also been proven and perceived by many people with a better condition, they experience faster changes of various problems faced, having previously suspected that these problems cannot be handled or deadlocked in handling, but by the miracle of Qur'an, it can be solved (including problems of autism).

One method that has a very big success, effective, and can be applied to all characteristics of autistichyperactive children in the absence of contra indications is with the Qur'an and methods of speech therapy. The Qur'an is the best methods or programs that are directly from Allah (Sofianah, 2010).

Allah said in the Qur'an: "O mankind, there come to you the lessons from your Lord and a healing for the diseases (that are) in the chest and guidance and mercy for those who believe" (QS. Yunus [10]:57) are stated "and when I am ill, He who will heal me" (QS. Asy-Syu'ara' [26]:80); "And we send down from the Koran, a cure (a drug) and a mercy to those who believe ..." (QS. Al Isra '[17]:82). In addition to the word of Allah, Muhammad said that "Find the cure, O servants of Allah. Allah has verily sent down a disease, but he also provides its cure anyway "(HR. Abu Dawud, Nasa'i, Tirmidhi, and Ibn Majah on Osama bin Syarik in Sofianah, 2010).

Based on the background of the problem, the researchers are interested in conducting a study with the title "Alquran Speech Therapy for Autistic Children". This study is conducted in the hope that it can help solve the problem in dealing with autistic children who need to be given special attention.

\section{METHOD}

This study used qualitative approach. It is an approach which emphasizes more on advantages and information collection by studying deeply phenomenon researched (Moleong, 2000). Qualitative study produces and analyzes descriptive data such as interview transcription, field note, pictures, photos, etc (Poerwandari, 1998). This study was designed through crosssectional, which means that it was conducted to a certain spot in August and September 2016. The subjects involved in this study consisted of 9 autism students with each aged 3 years (boys), 6 years (boys), 6 years (girls), 10 years (boys), 11 years (boys), 13 years (boys), 18 years (girls), 21 years (girls), 21 years (males).

This study was located in The Foundation/Autism Therapy Center Semarang at Afa Permai Houses No.1 Semarang. The method used to collect the data in this study was through interview to the subjects and significant other (head of the foundation, teachers, and parents of the students), and also through field note and observation techniques. The technique of data analysis was conducted through three phases namely (1) data reduction, (2) data presentation, and (3) conclusion or verification of research findings.

\section{RESULTSAND DISCUSSION}

Autism in Diagnostic and Statistical Manual of Mental Disorder R-IV is one of five kinds of disorder which is included in PDD (Pervasive Development Disorder) criterion consisting of, as follows. (1) Autistic Disorder (Autism) appears before 3 years old and is showed the existence of obstacles in social interaction, communication, and activities. (2) Asperger's Syndrome. Obstacles in social interaction and interest and limited activities, generally did not show late in language and speech, as well as having fair or more level intelligence. (3) Pervasive Developmental Disorder Not Otherwise Specified (PDD-NOS). Referring to the term of atypical autism, PDD-NOS diagnosis was applied if a child does not show the whole criteria on certain diagnosis (Autism, Asperger or Rett Syndrome). (4) Rett's Syndrome, or more often occurred to daughters and rarely to sons. They had ever experienced normal development then is occurred decline/ loss of ability they have; loss of functional ability of hands which was replaced by hand movements repeatedly ranged 1- 4 years old. (5) Childhood Disintegrative Disorder (CDD), showed normal development during 2 years of the first developmental phase then suddenly is occurred loss of abilities they achieved before. (6) Diagnosed pervasive Developmental Disorder Not Otherwise Specified (PDD NOS) was generally used or used in The United States of America to explain the existence of several autism characteristics on someone (Howlin, 1998, p. 79). 
It is different with National Information Center for Children and Youth with Disabilities (NICHCY) in The US, which states that Autism and PDD NOS are developmental disorders which tend to have similar symptoms similar characteristics whose symptoms appear before 3 years old. Those two things are neurological disorders which affect some abilities in communication, language understanding, play, and correlated to others.

In line with NICHCY, Baihaqi (in literatures 2011) states that autism disorders generally have three main dimensions of disorder namely (1) communication, language disorder through all efforts to communicate such as speaking, the intonation of hand movement, and face expression; (2) imagination, behavior and inflexibility of thinking process such as refusal on change, behavior, obsession, and ritualistic; (3) socialization, difficult in social interaction, lack of social time and empathy, refusal on normal physical contact and inappropriate eye contact.

Leaf, a researcher of NICHCY, mentions some factors causing autism, namely, Genetic susceptibility different genes may be responsible in different families Chromosome 7 speech language chromosome Variety of problems in pregnancy at birth or even after birth. Even though, the experts and the practitioners in autism cannot always agree or even be in line with the causes above. The most important thing to be taken into account through some previous studies is that autism disorder is not affected by psychological factors, such as because their parents did not want to have them when pregnancy period (Literatures, 2011).

Speech therapy is a must, because children with autism are late in speaking and difficult in using language. The purpose is too smoothen mouth muscles so that they can speak better. Almost all of the children have difficulties in speaking and using language. This is usually the most dominant, and it is also many individuals of autism children who have nonverbal or lack of speech ability. Sometimes, their speech is enough developed, but they are not able to use their speech to communicate/interact with others. In this case, speech and language therapy must be helpful (YPAC, p. 26-27).

Quran therapy has been explained in Quran. Allah SWT says in QS. Ar Rahman [55]: 1-4,

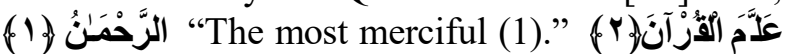

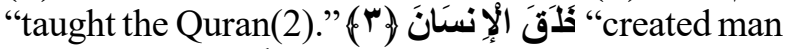

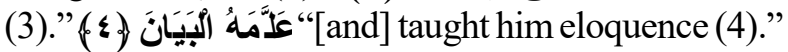
Yes, he is Allah SWT. He is the most merciful who has created human, revealed Quran that has become medicine and taught human to speak up. Based on this reason, Speech Therapist can combine Quran (Quran verses) and Sunnah. This great method has resulted awesome and effective formula (without medicine, witch, or any other condition to be filled) to treat children suffering from autism that affects communication disorder (language, talking, voice, and fluency rhyme). The result of the therapy could be seen and felt directly by family until nowadays. Besides, Allah SWT also says "Indeed Allah will not change the condition of a people until they change what is in themselves" (QS. Ar Ra'd [13]:11) "so ask the people of the message if you do not know" (QS. An Nahl [16]:43)

Based on the verse, children suffering from autism must be treated with good therapy. They also often suffer from specific learning disability. Teacher and parents regularly complained that the children often show unacceptable behavior when having task. The children either at home or at school were not easy to be disciplined by either the parents or the teacher. It was possibly caused by children's disability to finish their assignments as learning disorder.

Children with special needs such as autism and Attention Deficit Hyperactive Disorder (ADHD), must get special treatment. Therefore, parents and teacher need enough information to recognize dis-orders of their children earlier. They also need to know how to solve the problems well (Allex on Naning, 2015). Children suffering from autism are they who have attention only on their own world. It is the category of their disability to have good communication, social interaction, sensory disorder, game pattern, and emotional behavior. The incorrect understanding and perception will cause serious barrier to achieve their development in all aspects mainly social and communication ability. According to Allex (on Naning, 2015) Quran therapy is aimed to give children suffering from autism special treatment. They were asked to listen to the verses of Quran recitation. They listened to short verses twice in a day, in the morning after dhuha prayer and in the afternoon before napping. This therapy was an effective way to educate children suffering from Autism and ADHD.

The first step of this study was interview. The researcher interviewed children suffering from autism, chief of the foundation, teacher, and parents. It was aimed to measure the development of each child suffering from autism. The result showed that there were some differences between one child suffering from autism and others. However, most of them still could 
control their emotion. They also could give too many expressions. The next step was that the researcher observed some children suffering from autism. Based on the observation, the researcher found that there were 3 children suffering from autism who could not be treated by using verses of holy Quran through audio and visual method. It was caused that they had too many expressions when feeling something, for instances they often hit anything when feeling happy, they often got angry when feeling sad, etc. based on the finding, they were given special treatment. They were guided when they learned Quran. They were given short verses of juzz amma. The Surah included Al-Fatihah, An-Nas, Al-Ikhlas, Al-Falaq, and AlKautsar.

After being given the treatment, the result showed positive effects. 1) the children could get calm and control their emotion not to act too many expressions; 2 ) children suffering from autism felt happy when they hear verses recitation of Quran; 3 ) there was a child of 9 children suffering from autism could recite Al-Kautsar, 1 child also could recite Al-Fatikhah, 1 child could recite An-Nas although, they did not recite the surah fluently like other normal children.

\section{CONCLUSION}

Based on the research, the result can be concluded that there is positive effect of giving the children suffering from autism speech therapy with Quran recitation. They can be calm and happy in learning process. So, it is needed the follow up to this research relating to speech therapy by using Quran recitation to measure the development percentage that appears from the children suffering from autism.

\section{REFERENCES}

Adjeng, R.R.J., \& Hatta, M. I. (2015). Pengaruh Terapi ABA terhadap Interaksi Sosial Anak Autis di SLB Autis Prananda Bandung. Prosiding Penelitian Sivitas Akademika Unisba (Sosial Humaniora), 430-436.

Hartono, B., \& Popy, Y. (2014). Distribusi Faktor Risiko Autis di Jabotabek. Proposal Hibah Riset Kolaborasi. Jakarta: Fakultas Kesehatan Masyarakat UI.

Kusmitantia. (2012). Pembelajaran Tari Menggunakan Metode LEAP untuk Meningkatkan Sasaran Terapi Okupasi pada Anak Autis di SLB Bina Anggita Yogyakarta (Unpublished Undergraduate Thesis). Yogyakarta: Universitas Negeri Yogyakarta.
Marienzi, R. (2012). Meningkatkan Kemampuan Mengenal Konsep Angka melalui Metode Multisensori bagi Anak Autis. Jurnal Ilmiah Pendidikan Khusus EJupekhu, 3, 320-331. Retrieved from http://ejournal. unp.ac.id/index.php/jupekhu/article/view/822/679.

Moleong, L.J. (2000). Metodologi Penelitian Kualitatif. Bandung: Remaja Rosdakarya.

Pratiwi, et al. (2014). Hubungan Skor Frekuensi Diet Bebas Gluten Bebas Casein dengan Skor Perilaku Autis. Journal of Nutrition College, 3(1), 34-42. Retrieved from http://ejournal-s1.undip.ac.id/index.php/jnc/ article/view/4525/4350.

Poerwandari, E.K. (1998). Penelitian Kualitatif dalam Penelitian Psikologi, Pengembangan Sarana Pengukuran dan Pendidikan Psikologi. Jakarta: UI Press.

Melissa, F. (2013, April 2013). 112.000 Anak Indonesia Diperkirakan Menyandang Autisme. Republika. Retrieved from http://www.republika.co.id/berita/nasio nal/umum/13/04/09/mkz2un-112000-anak-indonesiadiperkirakan-menyandang-autisme.

Sastra, G. (2011). Neurolinguistik: Suatu Pengantar. Bandung: Alfabeta.

Setia, D. (2013). Diagnosis Akurat, Pendidikan Tepat dan Dukungan Kuat untuk Menciptakan Masa Depan Anak Autis yang Lebih Baik. Republika. Retrieved from http:/www. republika.co.id/berita/nasional/ umum/13/04/09/mkz2un-112000-anak-indonesiadiperkirakan-menyandang-autisme.

Sofianah, B. (2010). Intervensi Penanganan Autis-Hiperaktif dengan Menggunakan Al-Quran [Blog post]. Retrieved from http://antonherwanto.blogspot.co.id /2010/11/intervensi-dini penanganan-autis.html.

Sukmawati. (2014). Keefektifan Metode Picture Exchange Communication System (PECS) dalam Meningkatkan Kemampuan Berbahasa Anak Autis (Unpublished doctoral dissertation). Pascasarjana Universitas Negeri Malang, Malang.

Suryawati, et al. (2010). Model Komunikasi Penanganan Anak Autis melalui Terapi Bicara Metode LOVAAS. Jurnal Ilmiah Fakultas Ilmu Sosial dan Ilmu Politik, 1 (1), 27-37. Retrieved from https://ojs.unud.ac. id/index.php/widya/article/view/3678/2706.

Wijaya, H.N. (2015). Penanganan Khusus Anak Autis dan ADHD [Blog post]. Retrieved from http://solider.or.id /2015/01/24/penanganan-khusus-anak-autis-danadhd.

Yayasan Pembinaan Anak Cacat. (2010). Buku Pedoman Penanganan dan Pendidikan Autisme. Retrieved from http://ypacnasional.org/ebook/buku\%20pe nanganan $\% 20$ dan $\% 20$ Pendidikan $\% 20$ Autis $\%$ 20di\%20YPAC\%207April.pdf. 